\title{
IMPLEMENTASI TEORI KOMUNIKASI SOSIAL BUDAYA DALAM PEMBANGUNAN INTEGRASI BANGSA
}

\author{
Suranto Aw \\ Ilmu Komunikasi Universitas Negeri Yogyakarta \\ suranto@uny.ac.id
}

\begin{abstract}
Development is a process that is carried out continuously in a region over time. Development leads the improvement of the lives and well-being, both in terms of material and nonmaterial. To Indonesia, the development process is a planned activity to achieve national goals as mandated in the 1945 Constitution, which among others, to promote the general welfare, united, sovereign, fair, and prosperous. Indicators of well-being are not just limited to the economic aspect and materialistic, but also concerning aspects of harmony, unity, and integration of national life in dignity characterized by solidarity excellence. So that it is needed to consider the implementation of the theories of social and cultural communication in the development process.
\end{abstract}

\begin{abstract}
Abstrak
Pembangunan adalah suatu proses yang dilakukan secara terus menerus pada suatu wilayah dari waktu ke waktu. Pembangunan bermuara para peningkatan kehidupan dan kesejahteraan, baik dari sisi material maupun nonmaterial. Bagi Bangsa Indonesia, proses pembangunan adalah aktivitas terencana untuk mencapai tujuan nasional sebagaimana diamanatkan dalam Pembukaan UUD 1945, yaitu antara lain untuk memajukan kesejahteraan umum, bersatu, berdaulat, adil, dan makmur. Indikator kesejahteraan tidak hanya terbatas pada aspek ekonomis dan materialistis, melainkan juga menyangkut aspek keharmonisan, kebersamaan, dan integrasi hidup berbangsa secara bermartabat yang ditandai oleh adanya solidaritas yang prima. Berkenaan dengan itu, perlu dipertimbangkan implementasi teori-teori komunikasi sosial budaya dalam proses pembangunan.
\end{abstract}

Keywords: Socio-Cultural Communication, Growth, Integration

\section{PENDAHULUAN}

Pembangunan adalah suatu proses yang dilakukan secara terus menerus pada suatu wilayah dari waktu ke waktu dalam rangka mencapai peningkatan kehidupan dan kesejahteraan, baik dari sisi material maupun non material. Bagi Bangsa Indonesia, proses pembangunan adalah aktivitas terencana untuk mencapai tujuan nasional sebagaimana diamanatkan oleh Pembukaan UUD 1945, yaitu antara lain untuk memajukan kesejahteraan umum. Indikator kesejahteraan tidak hanya terbatas pada aspek ekonomis dan materialistis, melainkan juga menyangkut aspek keharmonisan dan kebersamaan hidup berbangsa secara bermartabat.

Kondisi bangsa Indonesia yang berbhinneka dalam banyak hal, terutama pada aspek budaya dan adat istiadat perlu dikelola dengan sebaik-baiknya agar perbedaan itu menjadi potensi yang secara sinergis saling melengkapi. Sementara itu keberhasilan proses pembangunan memerlukan dukungan dari berbagai pihak. Salah satunya adalah me- 
manfaatkan berbagai jenis media massa dalam proses pembangunan.

Media massa mempunyai fungsi yang sangat penting bagi kehidupan masyarakat. Fungsi media massa sangat menentukan dalam penyebarluasan informasi, pencerahan, dan peningkatan wawasan terhadap berbagai kebijakan pemerintah. Sejalan dengan tingkat perkembangan teknologi komunikasi yang kian pesat, maka terbuka peluang untuk mengoptimalkan fungsi media massa untuk mendukung pembangunan bangsa. Hal ini disebabkan ketersediaan media massa semakin memadai, baik secara kuantitas maupun kualitas. Terlebih ketika media daring (online) sudah berkembang pesat, maka akan mendukung kinerja media massa cetak dan elektronik. Beberapa studi dalam kajian komunikasi pembangunan menunjukkan bahwa media dapat menunjang suksesnya pembangunan. Locker (2004: 246) mengatakan media massa sebagai lembaga sosial dalam operasionalnya menunjukkan peran sebagai agen pembangunan, yaitu sebagai media informasi, edukasi, dan hiburan dalam rangka mendukung proses pembangunan bangsa.

Seiring semakin pesatnya perkembangan teknologi komunikasi, maka pemanfaatan media komunikasi massa menjadi semakin besar. Media televisi, radio, surat kabar, bahkan internet menjadi sarana menyampaikan pesan-pesan pembangunan kepada masyarakat. Media yang semakin canggih amat memungkinkan mengemas pesan pembangunan menjadi semakin kreatif dan menarik, dan menyebarkan informasi secara merata sehingga dapat menggugah dan meningkatkan partisipasi masyarakat.

Hasil penelitian Ali Murtadha (2009: 206) menunjukkan, sistem informasi pemerintah dan media massa mempunyai peran yang penting untuk mensukseskan pembangunan. Sistem informasi yang baik, bisa menciptakan kesatuan gerak dan langkah antar lembaga/dinas, antardaerah, untuk mencapai tujuan. Sistem informasi yang baik memungkinkan program-program dan kegiatan yang dilakukan pemerintah bisa direspon oleh masyarakat sehingga bisa mening- katkan partisipasi masyarakat.

Masyarakat memiliki kebutuhan dan motif beraneka ragam berdasarkan karakteristiknya sosialnya. Blumler, Katzdan Gurevitch membuat tipologi kebutuhan manusia yang berhubungan dengan penggunaan media yakni: kebutuhan kognitif, afektif, integratif pesan, integratif sosial dan kebutuhan akan pelarian. Budiman (2011: 11) menjelaskan, berbagai kebutuhan masyarakat ini dapat terpenuhi dan dipuaskan melalui media massa dan sumber lain. Melalui sumber lain, yakni kebutuhan ini terpenuhi dengan informasi dari pemerintah, hubungan keluarga, teman, komunikasi interpersonal, maupun mengisi waktu luang dengan berbagai cara.

Pendapat senada juga dikemukakan Rochayat Harus dan Elvinaro Ardianto (2011: 33) bahwa masyarakat Indonesia adalah tipe masyarakat yang bersifat plural. Di dalam masyarakat, berkembang motif dan kebutuhan yang beragam, menimbulkan arah perbuahan sosial yang dinamis, sehingga komunikasi di masyarakat juga harus mempunyai basis toleransi.

Integrasi atau persatuan bangsa, pada masa perjuangan kemerdekaan adalah merupakan faktor kunci yaitu sebagai sumber semangat, motivasi, dan penggerak perjuangan Indonesia. Hal itu tercantum dalam Pembukaan UUD 1945 yang berbunyi: "Dan perjuangan pergerakan Indonesia telah sampailah pada saat yang berbahagia dengan selamat sentausa mengantarkan rakyat Indonesia ke depan pintu gerbang kemerdekaan negara Indonesia yang merdeka, bersatu, berdaulat, adil, dan makmur".Persatuan dan kesatuan sangat penting bagi pembangunan bangsa karena melalui hal itu, bangsa tersebut dapat dengan mudah mencapai kemajuan.

Dalam konteks mewujudkan masyarakat Indonesia yang integratif, maka proses pembangunan harus senantiasa mengedepankan nilai-nilai substansial dalam upaya pemberdayaan potensi masyarakat guna mewujudkan toleransi dan rasa saling menghargai. Komunikasi dan interaksi antaranak bangsa juga perlu menjunjung tinggi toleransi atas berbagai perbedaan budaya. Proses komunikasi yang menghormati kebhinnekaan 
merupakan nafas yang menggerakkan kesadaaran membangun seluruh potensi kekuatan bangsa. Tanpa komitmen toleransi itu, diduga akan membuka peluang terjadinya ekses-ekses destruktif dalam masyarakat.

Integrasi bangsa Indonesia yang kita rasakan saat ini terjadi dalam proses yang dinamis dan berlangsung lama karena persatuan dan kesatuan bangsa terbentuk dari proses yang tumbuh dari unsur-unsur sosial budaya masyarakat Indonesia sendiri, yang ditempa dalam jangkauan waktu yang lama. Unsurunsur sosial budaya itu antara lain sifat kekeluargaan dan jiwa gotong-royong. Kedua unsur itu merupakan sifat-sifat pokok bangsa Indonesia yang dituntun oleh asas kemanusiaan dan kebudayaan.

Masuknya kebudayaan dari luar melalui proses akulturasi (percampuran kebudayaan), misalnya kebudayaan Hindu, Islam, Kristen, dan unsur-unsur kebudayaan lain yang beraneka ragam telah mendorong dinamika kekayaan budaya bangsa. Sikap toleransi harus selalu dipelihara agar interaksi sosial berlangsung secara dinamis dengan saling menghargai. Dengan toleransi yang baik, maka perbedaan budaya dapat diolah menjadi sumberdaya dalam mewujudkan proses komunikasi yang humanis, bermartabat, kekeluargaan, dan mengedepankan musyawarah. Perbedaan latar belakang budaya, seringkali menjadi kendala dalam proses komunikasi. Hal ini disebabkan adanya ukuran nilai baik-buruk, dan benar-salah yang berbeda. Untuk mengatasi kendala tersebut, dapat dilakukan dengan proses adaptasi dan toleransi yaitu penyesuaian dan penghargaan terhadap nilai-nilai sosial budaya yang berbeda.

\section{PEMBAHASAN}

\section{Komunikasi Sosial Budaya}

Masyarakat Indonesia sejak dulu sudah dikenal sangat heterogen dalam berbagai aspek, seperti adanya keberagaman suku bangsa, agama, bahasa, adat istiadat dan sebagainya. Di lain pihak, perkembangan dunia yang sangat pesat saat ini dengan mobilitas dan dinamika yang sangat tinggi, telah menyebabkan dunia menuju ke arah "desa dunia” (global village) yang hampir tidak memiliki batas-batas lagi sebagai akibat dari perkembangan teknologi modern, khususnya teknologi komunikasi. Dengan teknologi komunikasi interaksi dan pertukaran informasi menjadi mudah dan cepat. Kendala geografis sudah tidak menjadi persoalan. Setiap orang dengan mudah mengakses informasi yang asalnya dari berbagai tempat di berbagai belahan dunia. Berbarengan dengan pertukaran informasi tersebut, terjadi pula proses pertukaran nilai-nilai sosial budaya.

Oleh karenanya masyarakat (dalam arti luas) harus sudah siap menghadapi situasi-situasi baru dalam konteks keberagaman kebudayaan atau apapun namanya. Interaksi dan komunikasi akan melibatkan orang-orang dari berbagai latar belakang sosial budaya. Dalam berkomunikasi dengan konteks keberagaman latar belakang sosial budaya, seringkali menemui masalah atau hambatan-hambatan yang tidak diharapkan sebelumnya. Misalnya saja dalam penggunaan bahasa, lambang-lambang, nilai atau norma-norma masyarakat dan lain sebagainya.

Tema pokok yang membedakan studi komunikasi sosial budaya dari studi komunikasi lainnya ialah derajat perbedaan latar belakang, pengalaman sosial budaya antara komunikator dan komunikan. Sebagai asumsi dasar adalah bahwa di antara individu-individu dengan kebudayaan yang sama umumnya terdapat kesamaan (homogenitas) yang lebih besar dalam hal latar belakang pengalaman secara keseluruhan dibandingkan dengan mereka yang berasal dari kebudayaan berlainan. Perbedaan-perbedaan kebudayaan antara para pelaku komunikasi ini serta perbedaan lainnya, seperti kepribadian individu, umur, penampilan fisik, menjadi permasalahan inheren dalam proses komunikasi. Dengan sifatnya yang demikian, komunikasi sosial budaya dianggap sebagai perluasan dari bidang-bidang studi komunikasi manusia, seperti komunikasi antarpribadi, komunikasi organisasi dan komunikasi massa.

Dalam perkembangannya teori komu- 
nikasi sosial budaya telah menghasilkan sejumlah definisi. Komunikasi antarbudaya adalah komunikasi yang terjadi di antara orang-orang yang memiliki kebudayaan yang berbeda (bisa berbeda ras, etnik, atau sosioekonomi, atau gabungan dari semua perbedaan ini. Kebudayaan adalah cara hidup yang berkembang dan dianut oleh sekelompok orang serta berlangsung dari generasi ke generasi (Tubbs, Moss:1996).

Sitaram (1970) menjelaskan, komunikasi antarbudaya adalah seni untuk memahami dan dipahami oleh khalayak yang memiliki kebudayaan lain. Pendapat yang hampir sama dikemukakan Rich (1974), komunikasi bersifat sebagai komunikasi sosial apabila terjadi diantara orang-orang yang berbeda latar belakang sosial seperti strata sosial, pelapisan sosial, pranata sosial, dan sebagainya.

Sementara itu Stewart (1974) mendeskripsikan pengertian komunikasi sosial budaya lebih komprehensif, yakni komunikasi yang terjadi dalam suatu kondisi yang menunjukan adanya perbedaan latar belakang sosial budaya seperti strata sosial, bahasa, nilai-nilai, adat, dan kebiasaan. Young Yung Kim (1984) menegaskan, komunikasi sosial budaya menunjuk pada suatu fenomena komunikasi di mana para pesertanya memiliki latar belakang sosial dan budaya yang berbeda, terlibat dalam suatu kontak antara satu dengan lainnya, baik secara langsung atau tidak langsung.

Berdasarkan beberapa definisi tersebut, dapat dibuat simpulan pengertian komunikasi sosial budaya, ialah proses komunikasi yang melibatkan orang-orang yang berasal dari lingkungan sosial budaya yang berbeda. Komunikasi sosial budaya terjadi ketika dua atau lebih orang dengan latar belakang sosial budaya yang berbeda berinteraksi. Konsekuensinya adalah terjadinya interaksi nilai dan norma yang saling berbeda sehingga berpotensi mengganggu keefektifan komunikasi.

Nilaiadalah prinsip-prinsip etika yang dipegang dengan kuat oleh individu atau kelompok sehingga mengikatnya dan lalu sangat berpengaruh pada perilakunya. Nilai berkaitan dengan gagasan tentang baik dan buruk, yang dikehendaki dan yang tak dikehendaki. Nilai membentuk norma,yaitu aturan-aturan baku tentang perilaku yang harus dipatuhi oleh setiap anggota suatu unit sosial sehingga ada sanksi negatif dan positif. Norma sendiri ada berbagai tingkatan, yaitu: (1) adat istiadat (folkways), misalnya cara makan dan cara berpakaian; (2) mores, yaitu sistem aturan tidak tertulis; dan (3) hukum (law) yakni sistem atura tertulis dan perlanggarnya bisa dipenjarakan.

Norma sosial budaya adalah ketentuan baik dan buruk yang dipakai sebagai acuan manusia dalam berinteraksi di lingkungan sosial budaya. Apabila tindakan sesuai dengan norma sosial budaya, maka tindakan itu dikategorikan baik. Norma sosial budaya tersebut merupakan kesepakatan yang telah dibakukan atau dilembagakan. Norma sosial budaya dapat diganti dengan norma yang baru, apabila didukung oleh kesepakatan yang baru pula. Norma sosial budaya yang telah berjalan dalam waktu yang cukup lama, menjelma menjadi adat istiadat atau tradisi.

Ada satu budaya adat orang Jawa yang terkenal yaitu budaya mangan ora mangan waton ngumpul. Ungkapan tersebut menunjukkan betapa orang Jawa menghargai pentingnya hidup rukun, persahabatan, pergaulan, atau perjumpaan antar manusia. Adanya adat istiadat yang tidak tertulis ini, menjadi sebab mengapa orang Jawa pada umumnya hidup tenang dan bebas dari ketegangan. Dalam kehidupan sehari-hari, setiap kesempatan digunakan untuk memelihara silahturami di antara kerabat maupun kawan. Berkunjung ke tempat saudara atau teman lama tidak pernah dilewatkan, apalagi bila sudah lama tidak bertemu. Mengunjungi teman atau tetangga yang kesusahan selalu diusahakan. Melawat kenalan yang mengalami musibah atau orang meninggal merupakan kewajiban tak tertulis.

Ada lagi norma sosial budaya yang sejalan, yaitu "tuna satak bathi sanak". Artinya rugi harta tetapi untung dapat saudara. Memang untuk menjalin silaturahmi itu diperlukan biaya. Untuk mudik lebaran juga diperlukan biaya yang cukup besar. Tetapi hal itu tidak menjadi masalah, tidak masalah 
rugi harta, karena dari silaturahmi itu akan memperoleh keuntungan yang lebih besar nilainya, yaitu sanak, atau saudara, atau terbinanya ikatan famili, silaturahmi, dan integrasi sosial.

Dalam kehidupan sehari-hari komunikasi sosial budaya adalah merupakan jenis komunikasi yang sangat dominan, frekuensi terjadinya sangat tinggi. Mengapa? Karena peluang berinteraksi dengan orang berbeda latar belakang sosial dan budaya memang sangat besar. Komunikasi antara orang yang berbeda usia, jenis kelamin, status sosial ekonomi, agama, afiliasi politik, dan sebagainya akan selalu terjadi.

Contoh komunikasi sosial budaya sebagai berikut,bahwa kontak mata dianjurkan selama berkomunikasi di Medan. Ini adalah nilai budaya yang dijunjung tinggi di sana. Bila orang berbicara kepada penduduk Medan dengan menghindari kontak mata, maka ia dianggap menyembunyikan sesuatu atau tidak berkata benar, dan juga dianggap tidak mengindahkan etika. Coba bandingkan dengan nilai sosial budaya di Jawa, justru ketika berkomunikasi dengan orang yang lebih tua dianjurkan untuk menunduk dan tidak menatap langsung ke wajahnya.

Bahasa dapat terjadi dalam area baik verbal maupun nonverbal. Khususnya, komunikasi nonverbal sangat rumit, multidimensional, dan biasanya merupakan proses yang spontan. Orang-orang tidak sadar akan sebagian besar perilaku nonverbalnya sendiri, yang dilakukan tanpa berpikir, spontan, dan tidak sadar (Samovar, Larry A. dan Richard E. Porter, 1994). Kita biasanya tidak menyadari perilaku kita sendiri, maka sangat sulit untuk menandai dan menguasai baik perilaku verbal maupun perilaku nonverbal dalam budaya lain. Kadang-kadang kita merasa tidak nyaman dalam budaya lain karena kita merasa bahwa ada sesuatu yang salah. Khususnya, bahasa nonverbal, isyarat atau simbol yang digunakan memiliki makna yang tidak sesuai dengan yang kita ketahui selama ini. Misalnya untuk memberitahukan adanya suasana berkabung ada masyarakat yang menggunakan bendera warna putih (Yogyakarta), merah (Surakarta), kuning (Ja- karta), hitam (Jawa Timur).

Pada hakikatnya komunikasi sosial budaya menjunjung tinggi asas kesetaraan dan keterbukaan meskipun berbeda latar belakang sosial budayanya. Bahkan adanya perbedaan latar belakang sosial budaya harus disikapi secara arif sehingga tidak timbul kesenjangan, tetapi justru dapat memperkaya pengalaman.

\section{Implementasi Teori Komunikasi Sosial Budaya}

Setiap manusia hidup dalam suatu lingkungan sosial budaya tertentu. Setiap lingkungan sosial budaya itu senantiasa memberlakukan adanya nilai-nilai sosial budaya yang diacu oleh warga masyarakat penghuninya. Dengan demikian pola perilaku dan cara berkomunikasi akan diwarnai oleh keadaan, nilai, kebiasaan yang berlaku di lingkungannya. Melalui suatu proses belajar secara berkesinambungan setiap manusia akan menganut suatu nilai yang diperoleh dari lingkungannya. Nilai-nilai itu diadopsi dan kemudian diimplementasikan dalam suatu bentuk "kebiasaan", yaitu pola perilaku hidup sehari-hari. Dengan demikian pola perilaku seseorang dalam berkomunikasi dengan orang lain, akan dipengaruhi oleh nilainilai yang diperoleh dari lingkungan sosial budayanya.

Oleh karena setiap individu memiliki lingkungan sosial budaya yang saling berbeda dengan yang lain, maka situasi ini menghasilkan karakter sosial budaya setiap individu bersifat unik, khusus, dan berbeda dengan orang lain. Meskipun berasal dari keluarga yang sama, karakter seseorang tidaklah sama persis dengan anggota keluarga lainnya karena lingkungan sosial tidak terbatas pada keluarga, melainkan mencakup teman sebaya, masyarakat, sekolah, media massa, dan sebagainya.

Budaya dan komunikasi tak dapat dipisahkan oleh karena budaya tidakhanya menentukan siapa bicara dengan siapa, tentang apa, dan bagaimana orangmenyandi pesan, tetapi juga makna yang ia miliki untuk pesan dan kondisi-kondisinya untuk mengirim, 
memperhatikan dan menafsirkan pesan. Sebenarnyaseluruh perbendaharaan perilaku kita sangat bergantung pada budaya tempat kitadibesarkan. Konsekuensinya, budaya merupakan landasan komunikasi. Bilabudaya beraneka ragam, maka beraneka ragam pula praktik-praktik komunikasi.

Implementasi teori komunikasi sosial budaya diharapkan dapat mengembangkan tanggung jawab sosial. Prisip-prinsip komunikasi sosial budaya perlu diimplementasikan dalam kehidupan sehari-hari agar tercipta keharmonisan dan integrasi berbangsa. Pada dasarnya semua komponen masyarakat perlu memahami prinsip-prinsip komunikasi sosial budaya, namun salah satu pihak yang dipandang memiliki posisi strategis adalah para pengelola media, para pemuka pendapat, dan komponen sumber informasi lainnya. Dengan menerapkan teori komunikasi sosial budaya, sumber informasi dan pengelola media dapat terpandu untuk mencintai kebajikan dan kebenaran. Mengedukasi masyarakat dengan konten informasi yang dikemas secara independen dan transparan, mengutamakan kebenaran, dan menghargai perbedaan latar belakang sosial budaya.

Tujuan kajian tentang komunikasi sosial budaya adalah untuk mengantarkan kepada suatu kompetensi pengetahuan bahwa perbedaan latar belakang sosial budaya dapat mengakibatkan kurang efektifnya proses komunikasi. Dengan studi ini tidak hanya menekankan bagaimana orang yang saling berbeda latar belakang sosial budaya dalam berbicara, tetapi bagaimana mereka bertindak antarorang dan bagaimana mereka mengikuti aturan-aturan terselubung yang mengatur perilaku anggota masyarakat yang memiliki acuan nilai sosial dan budaya saling berbeda. Dengan menerapkan prinsip komunikasi sosial budaya diharapkan: (a) memahami bagaimana perbedaan latar belakang sosial budaya mempengaruhi praktik komunikasi; (b) mengidentifikasi kesulitankesulitan yang muncul dalam komunikasi sosial budaya; (c) meningkatkan keterampilan verbal dan nonverbal dalam berkomunikasi sehingga mampu berkomunikasi efektif.

Interaksi sosial di masyarakat merupa- kan suatu bentuk komunikasi yaitu komunikasi antaindividu, anarkelompok, antarmasyarakat. Di dalam komunikasi tersebut terdapat pembentukan (transformasi) dan pengalihan (transfer) pengetahuan, keterampilan ataupun sikap dan nilai dari komunikator (pemuka pendapat, pengelola media, indivudu) kepada komunikan (individu dan masyarakat) sesuai dengan tujuan yang telah ditetapkan.

Pada hakikatnya komunikasi sosial budaya menjunjung tinggi asas kesetaraan antara komunikator dan komunikan. Bahkan adanya perbedaan latar belakang budaya antara komunikator dan komunikan harus disikapi secara arif sehingga tidak timbul kesenjangan, tetapi justru dapat memperkaya pengalaman. Berdasarkan prinsip memaklumi perbedaan latar belakang sosial budaya ini, maka implementasinya dalam proses komunikasi dapat diuraikan berikut ini.

Pertama, setiap individu memiliki nilainilai sosial budaya dan berhak menggunakan nilai-nilai itu.Dalam hal ini komunikator dan komunikan yang saling berbeda latar belakang budaya, harus bisa saling menghargai. Apabila terjadi perbedaan penafsiran dan pemaknaan atas lambang-lambang tertentu, hal itu harus dimaklumi dan dipergunakan sebagai awal untuk saling berbagi pengetahuan sehingga di kemudian hari dapat dilakukan komunikasi yang efektif, yang ditandai oleh adanya kesamaan pengalaman dalam memberi arti simbol-simbol oleh komunikator dan komunikan.

Kedua, seting interaksi sosial mengikuti pola komunikasi horizontal dua arah, bukan vertikal satu arah. Seting horizontal, artinya posisi pihak-pihak yang berkomunikasi adalah sejajar. Komunikasi dua arah, berarti komunikator mesti membangun sistem komunikasi dua arah dengan, sehingga proses komunikasi pada hakikatnya adalah proses "berbagi".

Ketiga, empati merupakan kaidah emas untuk mengatasi ancaman kegagalan berkomunikasi.Kaidah emas mengasumsikan bahwa semua orang itu sama dalam hal memiliki perasaan. Semua orang adalah sama dalam hal: ingin memperoleh kesenangan, kesela- 
matan, keberhasilan, kenyamanan, dan sebagainya. Dengan kata lain, kalau kita melakukan suatu tindakan, kita harus selalu ingat, kalau kita tidak suka dipermalukan, maka semua orang juga sama: tidak berkenan apabila dipermalukan. Oleh karena itu empati sangat penting untuk dikembangkan dalam proses komunikasi di masyarakat.

Empati adalah memposisikan diri pada posisi orang lain. Empati menggambarkan pergeseran perspektif dari kita pada pengalaman orang lain yang berbeda. Pergeseran perspektif ini seringkali disertai dengan kesediaan berpartisipasi dalam pengalaman orang lain, paling tidak berperilaku yang sesuai dengan pengalaman itu.

Keempat, proses komunikasi tidak hanya mengajarkan pengetahuan, tetapi juga mendidik nilai-nilai sosial budaya. Untuk mewujudkan komunikasi yang bermakna bagi pengembangan manusia seutuhnya, maka dalam pertukaran informasi tidak hanya bermaksud transfer pengetahuan, tetapi juga transfer nilai-nilai sosial budaya.

Kelima, perlunya memahami karakteristik komunikan dan berusaha menyesuaikan cara berkomunikasi dengan karakteristik komunikan tersebut. Komunikator yang baik seyogyanya memahami karakteristik komunikannya agar ia sukses dalam melaksanakan perannya.

Keenam, komunikasi sosial budaya sebagai proses pertukaran informasi secara terbuka.Komunikasi secara terbuka diindikasikan oleh adanya peluang yang sama dari komunikator dan komunikan untuk menyampaikan gagasan. Kefektifan komunikasi yang didesain secara terbuka tersebut tergantung dari kedua belah pihak, namun, karena komunikator yang memegang kendali maka tanggungjawab terjadinya komunikasi yang sehat, terbuka dan efektif terletak di tangan komunikator.

\section{SIMPULAN}

Integrasi bangsa adalah suatu keadaan yang menunjukkan adanya kondisi yang harmonis, nyaman, teratur, dan saling solider meskipun dihadapkan pada berbagai perbedaan. Sebagai contoh, kondisi bangsa Indonesia menunjukkan adanya keharmonisan sosial, karena dalam negara kesatuan yang penduduknya terdiri dari berbagai suku bangsa, dan tersebar di berbagai daerah dalam kondisi yang berbeda-beda namun solidaritas dan kebersamaan dijunjung tinggi.

Bangsa Indonesia berbeda baik dalam hal lingkungan alam, dalam hal kesejahteraan hidup, kesempatan pendidikan, pilihan politik, agama dan interestnya, dan sebagainya. Keanekaragaman ini, jika dikelola secara baik, akan menjadikan khazanah ke-Indonesia-an yang luar biasa. Tetapi sebaliknya, jika perbedaan-perbedaan itu, tidak dikelola secara baik, maka perbedaan-perbedaan dimaksud akan menjadi persoalan, yang pada ujungnya akan memunculkan ketidakharmonisan dan konflik.

Ketidakharmonisan dan konflik hampir pasti akan memperlemah dan memperlambat kemajuan pembagunan Indonesia dalam persaingan dengan negara-negara berkembang lainnya. Apalagi dengan negara-negara yang terlebih dahulu sudah maju. Salah satu upaya untuk menjaga integrasi bangsa adalah dengan meningkatkan penerapan prinsip komunikasi sosial budaya. Dalam hal ini interaksi antar anak bangsa harus menjujung tinggi solidaritas dan toleransi terhadap perbedaan nilai-nilai sosial budaya.- 


\section{DAFTAR PUSTAKA}

Ali Murtadha. 2009. "Sistem Informasi Pemerintah Kabupaten Aceh Tengah" dalam Jurnal Penelitian Komunikasi dan Pembangunan. Vol 10. No. 1. Balai Besar Pengkajian dan Pengembangan Komunikasi dan Informatika. Medan.

Budiman. 2011. "Telepon Seluler dan Efektivitas Komunikasi Pedesaan" dalam Jurnal Penelitian Komunikasi dan Pembangunan. Vol 12. No. 2. Balai Besar Pengkajian dan Pengembangan Komunikasi dan Informatika. Medan.

Kitty O. Locker.2004. Business and Administrative Communication. Boston: McGraw-Hill Irwin.

Stewart L. Tubbs \& Sylvia Moss. 2005. Human Communication. Buku Pertama \& Kedua. Bandung: PT Remaja Rosdakarya.

Rochayat Harun \& Elvinaro Ardianto. 2011. Komunikasi Pembangunan dan Perubahan Sosial. Jakarta: PT Rajagrasindo Persada. 